\title{
Henrik Tikkanens sociologiska mikrokosmos
}

Den finlandssvenska författaren, bildkonstnären och journalisten mellan den kommersiella och konstnärliga polen

De nya biografierna om Märta Tikkanen, Siv Storås ${ }^{1}$ och Johanna Holmströms, ${ }^{2}$ samt Matilda Torstensson Wulfs doktorsavhandling om makarna Tikkanens litterära dialog och förutsättningarna för skapande, skrivande och romantiska parförhållanden ${ }^{3}$ belyser också Henrik Tikkanen som person. De gör honom även aktuell i dagens litterära debatt. ${ }^{4}$

Henrik Tikkanen-forskningen bestod länge endast av separata kortare studier; som tre exempel härpå kan nämnas Pirkko Alhoniemis finskspråkiga studie om identitetssökande och hemlöshetskänslor i författarens verk, ${ }^{5}$ Andrzej Chojeckis artikel på polska om Tikkanen som författare i krigs- och fredstid ${ }^{6}$ och Georg Blechers essä om

I. Siv Storå, De oerbörda orden. En bok om Märta Tikkanens författarskap, Helsingfors: Schildts \& Söderströms 2020.

2. Johanna Holmström, "Borde bålla käft": En bok om Märta Tikkanen, Helsingfors: Förlaget 2020.

3. Matilda Torstensson Wulf, Kärlekens paradis: Konfikten mellan kärlek och konst $i$ Henrik och Märta Tikkanens litterära dialog, Lund: Ellerströms förlag 202I.

4. Henrik Meinanders bok, Tikkanens linje. Tidsbilder 1967-1972, Helsingfors: Schildts \& Söderströms 202I, som i tio essäer behandlar Tikkanens samhällsorienterade och kulturpolitiska teckningar i Helsingin Sanomat från åren 1967-1972, beaktas inte här då den inte utkommit vid tidpunkten då denna artikel färdigställts för tryck.

5. Pirkko Alhoniemi, "Kuka pitäisi minua omanaan? Identiteetin etsintä ja kodittomuuden tunnot Henrik Tikkasen tuotannossa", Kaisa Kurikka (toim.), Identiteettiongelmia suomalaisessa kirjallisuudessa, Turku: Turun yliopisto I995, s. 94-I2I.

6. Andrzej Chojecki, "Zapite pokolenie. Henryk Tikkanen o czasie wojny i czasie pokoju", Zeszyty Naukowe Wydziatu Humanistycznego, Studia Scandinavica 7, Gdansk: Uniwersytet Gdański I984, s. 43-58. 
Tikkanen som berättare ${ }^{7}$. Ett mera omfattande forskningsarbete var min egen bourdieuskt och receptionsmässigt inriktade doktorsavhandling på tjeckiska om Tikkanen-Kihlman-debatten i mitten av 1970-talet; ${ }^{8}$ en kortare sammanfattning av avhandlingen finns till förfogande också på svenska. ${ }^{9}$ På svenska analyserar jag också Tikkanen som en tvåspråkig finländsk författare som använde både svenska och finska som arbetsmedel. ${ }^{10}$ Särskilt efter millennieskiftet har Tikkanen uppmärksammats av flera finländska litteratörer och forskare, också med anledning av att det löpt åttio år sedan hans födelse 1924 och tjugo år sedan hans död 1984. Som författare har han behandlats av Johan Wrede och som bildkonstnär av Erik Kruskopf i deras respektive biografier över Tikkanen, ${ }^{11}$ och som människa av hans änka Märta Tikkanen. ${ }^{12}$

Henrik Tikkanen var under sin levnadsbana verksam som författare, bildkonstnär och journalist. Det som präglar hans litterära verksamhet är en oerhört stor produktivitet: enligt uppslagsdelen i Finlands svenska litteraturhistoria är Tikkanen upphovsman till inalles 52 böcker författade antingen på svenska eller - i mindre skala - på finska, inklusive sagor, reseböcker, lyrik, dramatik, tv-dramer, hörspel, kåserisamlingar, bilderböcker, aforismer och romaner, memoarer (hågkomster, självbiografier) samt några genremässigt svårbestämbara verk. ${ }^{13} \mathrm{Om}$ man

7. Georg Blecher,'Tikkanens'ande'. Berättarrösten i Brändövägen 8", Horisont I994:I.

8. Jan Dlask, Debata Tikkanen-Kiblman. Preludium. Dila-prijetí-polemika. Disertační práce, opublicerad doktorsavhandling, Karlsuniversitetet, Prag 20 оо.

9. Jan Dlask,"Tikkanen-Kihlman-debatten. En bourdieusk analys av paradoxen i att revoltera inifrån", Historiska och litteraturbistoriska studier 87, Helsingfors: Svenska litteratursällskapet i Finland 20I2, s. 235-277.

Io. Jan Dlask, "Finskans rika valörer eller svenskans subtila nyanser? Den tvåspråkige författaren och konstnären Henrik Tikkanen", Heidi Grönstrand \& Kristina Malmio (red.), Både och, sekä että. Om flerspråkighet. Monikielisyydestä, Helsingfors: Schildts 20II, s. 246-268.

II. Johan Wrede, Tikkanens blick. En essä om Henrik Tikkanens författarskap, livsöde och personlighet, Helsingfors: Svenska litteratursällskapet i Finland \& Stockholm: Bokförlaget Atlantis 20I2; Erik Kruskopf, Tecknaren Tikkanen, Helsingfors: Söderströms 2004. Om Tikkanen som tecknare se även Märta Tikkanen (red.), Henrik, Helsingfors: Söderströms I985, s. 4, 47, 80, I03.

I2. Märta Tikkanen, Två. Scener ur ett konstnärsäktenskap, Helsingfors: Söderströms 2004.

I3. "Uppslagsdel", Clas Zilliacus (utg.), Finlands svenska litteraturhistoria. Andra delen. rgoo-talet, Helsingfors: Svenska litteratursällskapet i Finland \& Stockholm: 
därtill lägger de texter som han skrev som journalist så skulle listan vara ännu mycket längre. Likadant förhåller det sig med hans verksamhet som bildkonstnär; konsthistorikern Erik Kruskopf, författaren till biografin om bildkonstnären Tikkanen, nämner i sin bok att när Tikkanen fick välja ut arbeten för utställningen på Amos Andersons konstmuseum i Helsingfors så var detta ingen lätt uppgift - det gällde att välja mellan 30 ooo arbeten som han hade hemma. Listan över de bildkonstgenrer som Tikkanen sysslat med är likaså lång. ${ }^{14}$

I denna artikel görs en sociologisk tolkning av den konstnärliga mångsysslaren Henrik Tikkanen. Min studie vill pröva om den sociologiska metodologi Pierre Bourdieu använder i Les Règles de l'art (Konstens regler) samt i sina andra studier kan hjälpa till att klassificera verk ur så omfattande listor för att få en bättre översikt över hur enstaka alster av Tikkanen förhåller sig till varandra; med andra ord ämnar jag undersöka relevansen av min analysmodell, som beskrivs närmare nedan. I ett avseende blir min uppgift här tvådimensionell: min avsikt är att skissera ett slags syntes, en sociologisk bild av"Tikkanen inter artes”, det vill säga få klarhet i hur hans bildkonstnärliga och litterära verksamheter förhåller sig till varandra. Bourdieu påpekar många gånger att samma regler gäller på olika kulturella fält. I Konstens regler analyserar han både litteratur och bildkonst samt deras ömsesidiga förhållande, till exempel hur bildkonstnärer och författare umgicks med och inspirerade varandra; ${ }^{15}$ i den här studien är jag intresserad av hur Henrik Tikkanen som bildkonstnär och författare umgicks med sig själv.

Min studie består av två huvudavsnitt som står i ett slags samspel: i det första analyserar jag Tikkanen som gestalt i hans självbiografiska bok Bävervägen II Hertonäs (I976) som belyser början på hans karriär. Sedan övergår jag till att behandla honom som författare och bildkonstnär utgående från sekundära källor. Den här kombinationen väljer jag för att jag anser att den gör det möjligt att belysa hur Tikkanen såg på sig själv, först och främst i de inledande faserna av sin bana,

Bokförlaget Atlantis 2000, s. 440. En användbar sammanfattning av Tikkanens verksamhet som författare kan fås i Wrede, Tikkanens blick, s. 24-49.

I4. Kruskopf, Tecknaren Tikkanen, s. I2I.

I5. Pierre Bourdieu, Konstens regler: det litterära fältets uppkomst och struktur, Stockholm: Brutus Östlings Bokförlag Symposion 2000. 
eller trajectoire som Bourdieu kallar det på franska. Detta kompletteras med tolkning av de fakta som tillhandahållits utifrån av konstoch litteraturforskarna samt mottagandet av Tikkanens tre kanoniska böcker: Hjältarna är döda (1961), Ödlorna (1965) och Brändövägen 8 (1975). Bland forskarna bygger jag särskilt vidare på Kruskopf - som i många sammanhang implicit ser på Tikkanens verksamhet som en bana i bourdieusk mening. Även om Wredes perspektiv snarare är psykologiskt-biografiskt kan några av hans resultat likaledes användas här - han ser viljan att få grepp om högst personliga livsproblem som en drivande kraft bakom Tikkanens författarskap, som i Wredes argumentering i stor utsträckning handlar om livets existentiella villkor sådana dessa presenterade sig för män i Tikkanens generation och tid. ${ }^{16}$ Mina två huvudavsnitt följer varandra i stort sett kronologiskt.

Mitt mål är alltså att analysera Tikkanens verksamhet mera som en helhet snarare än att studera någon specifik del av den. Hans texter och bildkonst ses som delar av samma konstnärskap. Ämnet är således ganska brett. Vid sidan av de nedan beskrivna bourdieuska verktyg jag använder riktar sig mitt intresse speciellt mot kopplingen och parallellerna mellan författarens skönlitterära och bildkonstnärliga banor och även på dessas förhållande till hans journalistik. Mera ingående bildanalys är inte en central del av studien - även om den kan inspirera bourdieuskt orienterade och tikkanenskt intresserade konstvetare att utföra en sådan. Likaledes kan studien i tillägg till den tidigare nämnda artikeln ${ }^{17}$ utgöra en skiss till en mera omfångsrik litteraturvetenskaplig bourdieusk tolkning av Tikkanen endast som författare. ${ }^{18}$ Även enstaka alster av Tikkanen inbjuder till separata bourdieuska studier; en sådan är min egen inledande analys av Tikkanen som gestalt inom ramen för den här artikeln.

\section{Den "bourdieuska" och "gedinska" apparaten}

Ett av Bourdieus nyckelbegrepp är kapital med vilket menas inte bara materiella, utan också symboliska tillgångar. Såsom även Donald

I6. Wrede, Tikkanens blick, s. II.

I7. Jfr Dlask, "Tikkanen-Kihlman-debatten".

I8. T.ex. om hur Tikkanens habitus präglats av den finlandssvenska överklasstraditionen och/eller individuellt av familjens alkoholism och ekonomiska nedgång. 
Broady sammanfattar saken skiljs det i hans forskning mellan olika typer av kapital; de som behandlas i denna studie är ekonomiskt kapital (i den vanliga betydelsen materiella tillgångar), socialt kapital (släktband, vänskapsförbindelser, kontakter med gamla skolkamrater och så vidare) och symboliskt kapital (en immateriell tillgång som tillerkänns värde i vissa sammanhang, till exempel anseende i den litterära eller bildkonstnärliga världen). Den viktigaste utgångspunkten för all bourdieusk forskning är det fullt utvecklade kulturella fältet; fält kan generellt definieras som ett system av relationer mellan olika positioner. Varje utvecklat kulturellt fält präglas av två polariteter: en autonom, konstnärlig, estetiskt dominerande eller intellektuell ${ }^{19}$ pol (där fältets eget kapital står högt i kurs, konsten hyllas för konstens egen skull och konstnärerna och författarna framför allt tävlar om kritikernas, kollegernas och konkurrenternas uppskattning) och en heteronom kommersiell pol (där andra värden, som pekuniär vinning, publikframgång eller anseende hos tongivande kretsar på annat håll i samhället gäller). Dikotomin mellan (ren) konst och pengar är således särpräglad för Bourdieu. ${ }^{20}$

Bourdieus begrepp "strategi" ska uppfattas som aktörers försök mer eller mindre omedvetna - att värna värdet på sitt kapitalinnehav och att försvara eller förbättra sin position. En aktörs litterära eller konstnärliga bana kan bland annat studeras som ett brett spektrum av hens insatser i "spelet". De instanser som hallstämplar verk och deras skapare eller författare kallas för "konsekrationsinstanser" och omfattar bland annat litteratur- och konstkritiker, litteratur- och konsthistoriker, förlag och akademier. Vid den autonoma polen sker

I9. Begreppet "intellektuell" har stöd hos Broady. Se Donald Broady, "Inledning: en verktygslåda för studier av fält", Donald Broady (red.), Kulturens fält: en antologi, Göteborg: Daidalos I998, s. I-7, http://skeptron.uu.se/broady/sec/p-98-kulturensfalt-inledn-o-frontmatter.pdf (hämtad I6/II 2020). Polen i fråga kan ofta (dock inte alltid) anses som sådan bland de litterära aktörerna, men mindre bland bildkonstnärerna; ju mer autonomt det kulturella fältet är, desto mer dominerar ofta synen på de konstnärer/författare som befinner sig närmast den autonoma polen som "intuitiva" (dvs. inte intellektuella i bemärkelsen "tänkande" eller "lärda"). Det här är terminologiskt relevant speciellt i fallet Tikkanen då han som aktör spelar med både ett bildkonstnärligt och ett författande kapital. Tack till en av artikelmanuskriptets anonyma granskare för det här påpekandet.

20. Broady, "Inledning", s. I-7; Bourdieu, Konstens regler. 
konsekreringen långvarigt, vid den motsatta heteronoma polen tvärtom kortvarigt. ${ }^{21}$

Denna artikel knyter an inte bara till den bourdieuska forskningstraditionen, men också till David Gedins forskning. I den svenskspråkiga antologin Kulturens fält, som beskrivs som en första rapport från de nordiska provanstalterna - där utprovningen gäller av Bourdieu inspirerade sociologiska analyser av fält - hänvisar huvudredaktören Donald Broady till att även skönlitterära gestalter kan utnyttjas i sådana undersökningar. Bourdieu publicerade själv i97ı en läsning av Gustave Flauberts roman L'éducation sentimentale (1869, sv. Hjärtats fostran), som också ingår som ett slags prolog i hans studie Konstens regler. Med utgångspunkt i ett halvdussin av romankaraktärerna samt deras tillgångar i form av pengar, kultur, utbildning, adelstitlar, skönhet, deras positioner och deras sociala och geografiska banor (förflyttningar), rekonstruerade Bourdieu ett mikrokosmos som speglade I830- och I840-talens intellektuella fält i Paris. I den ovan nämnda, av Broady redigerade antologin presenterar David Gedin en motsvarande tolkning av August Strindbergs Röda rummet (1879);22 i det bourdieuska sammanhanget är Gedin mest känd för sin avhandling ${ }^{23}$, i vilken han tillämpar Bourdieus teorier om det autonoma litterära fältet $\mathrm{i}$ en analys av utvecklingen på I88o-talet, där han beskriver ett viktigt steg $i$ hur en modern författares identitet tar form i Sverige.

Liksom Gedin uppfattar jag den bourdieuska metodologiska apparaten som en inspiration till studier av också andra nationella eller språkliga fält än det franska. Jag genomför en analys som liknar både Bourdieus och Gedins; utgående från deras reflexioner ska jag förflytta mig från I80o-talets Frankrike respektive Sverige till I90otalets andra hälft i Finland, där Tikkanen bygger upp sin konstnärliga karriär. I ett avseende kan min uppgift vara lättare än deras: både

2I. Broady, "Inledning", s. I-7; Bourdieu, Konstens regler.

22. Jfr Broady,"Inledning", s. 8-9. Pierre Bourdieu,"Prolog. Flaubert analyserar Flaubert. En läsning av Hjärtats fostran”, Bourdieu, Konstens regler, s. 37-88; David Gedin,"Kalfstek och rosor. En studie i August Strindbergs strategier under 1870talet och självanalysen i Röda rummet", Donald Broady (red.), Kulturens fält: en antologi, Göteborg: Daidalos I998, s. 4I-78.

23. David Gedin, Fältets herrar: framväxten av en modern författarroll: artonhundraåttitalet, Stockholm: Brutus Östlings Bokförlag Symposion 2004. 
Bourdieu och Gedin fick förhålla sig till sättet på vilket "Flaubert [respektive Strindberg] analyserar Flaubert [respektive Strindberg]"24. Varken Hjärtats fostran eller Röda rummet är Flauberts eller Strindbergs självbiografi, men ändå säger de - åtminstone enligt skribenternas tolkning - någonting om det icke-fiktiva litterära fältet på vilket Flaubert och Strindberg rörde sig. Den skönlitterära text av Tikkanen som utgör material i de inledande avsnitten av min artikel är dock klart självbiografisk, skriven i traditionell jagform, vilket underlättar läsningen av författaren, konstnären och journalisten Tikkanen som (huvud)gestalt i boken.

\section{BÄVERVÄGEN 11 HERTONÄS (I976)}

Bävervägen II Hertonäs av Henrik Tikkanen - som i fråga om tolkningspotential visar många paralleller med Hjärtats fostran och Röda rummet - är den andra så kallade adressboken i Tikkanens självbiografiska svit. Den utspelar sig i I940- och I950-talens Helsingfors, efter andra världskriget, och följer tidsmässigt den första boken, Brändövägen 8 Brändö Tel. 35 (I975), som beskriver Tikkanens barndom och ungdom inklusive erfarenheterna från fronten under fortsättningskriget, och som slutar med att hans far dör. ${ }^{25}$

\section{Tikkanens habitus och frägan om arvet}

Om Tikkanens habitus - i bemärkelsen system av dispositioner som tillåter människan att handla, tänka och orientera sig, som grundläggs genom de vanor hon införlivar i familjen och skolan och som sedan fungerar som ett seglivat och ofta omedvetet handlingsmönster ${ }^{26}-$ berättar Kruskopf följande:

Få konstnärer har från hemmet varit så klart predestinerade till sitt kommande yrke som Henrik Tikkanen. Uppvuxen i ett hem med en far som var arkitekt och en farfar som var konsthistoriker - i Finland en banbrytare och den första innehavaren av en professur i detta

24. Jfr Bourdieu, "Prolog", s. 37.

25. Henrik Tikkanen, Brändövägen 8 Brändö Tel. 35, Helsingfors: Söderströms I975.

26. Broady, "Inledning", s. 2. 
ämne - låg det nära till hands att också barnen skulle börja ägna sig åt konst; Henriks halvbror Ulf blev skulptör. ${ }^{27}$

Bourdieu kallar detta för reproduktion; med andra ord kan man säga att Tikkanen föddes i en familj som hörde till den finlandssvenska eliten, den dominerande klassen som Bourdieu kallar det. Bourdieu skriver vidare att överförandet av makten från en generation till en annan alltid innebär ett kritiskt moment i en familjs historia. Det beror på att den relation av ömsesidig anpassning mellan det materiella, kulturella, sociala och symboliska fadersarvet och de biologiska individer som har utformats av och för anpassningen är hotad. ${ }^{28}$

Just ett sådant kritiskt moment beskriver Bävervägens första mening: "Efter fars begravning var det dags att dela arvet." ${ }^{29}$ För arvingarna, det vill säga Henrik själv och hans två äldre bröder som är tvillingar, finns det inte mycket att dela längre, för fadern har supit upp nästan hela sin förmögenhet - såsom Henrik Tikkanen så färgrikt beskrivit redan i Brändövägen 8. Det som finns kvar delas i tre delar; det är lägenheten, en värdefull egendom i bostadsbristens tider, där två familjer kan bo, och släktporträtten utan ekonomiskt värde. Precis som gruppen ynglingar, huvudgestalten Frédéric och hans vänner, i Hjärtats fostran, ${ }^{30}$ visar var och en av bröderna sin egen framtida strategi vid arvsskiftet: Henrik är glad över att ha fått tavlorna och tvillingarna får behålla sitt barndomshem. ${ }^{31}$

Tvillingarnas strategi, som bekräftas på de följande sidorna $\mathrm{i}$ Bävervägen ${ }^{32}$ är att skaffa sig ekonomiskt kapital genom att bli affärsmän. Henrik reflekterar däremot över porträttet av "[̈̈]rkebiskopen med de rosiga kinderna", ${ }^{33}$ det vill säga en av Tikkanens förfäder Jacob Tengström, som spelade en framträdande roll för Finland när landet lösgjordes från Sverige och införlivades med Ryssland åren I808-I809. Tikkanen formulerar det så att Tengström slöt fred i ett hopplöst

27. Kruskopf, Tecknaren Tikkanen, s. 9.

28. Bourdieu, "Prolog", s. 49.

29. Henrik Tikkanen, Bävervägen II Hertonäs, Helsingfors: Söderströms I976, s. 7.

30. Se Bourdieu, "Prolog".

31. Tikkanen, Bävervägen, s. 7. Angående släktporträttens betydelse för Henrik se även Storå, De oerbörda orden, s. 68.

32. Se Bävervägen, s. 7-I2.

33. Ibid., s. 8. 
läge när de ryska trupperna hade avancerat ända till Österbotten och därför senare ansågs vara en förrädare. ${ }^{34}$ "Och efter att igen i Sven Dufvas anda ha slagit pannan blodig mot ryssen var vi nu äntligen beredda hundra år efter biskopens död att erkänna hans klokhet och hans framsynthet $\mathrm{i}$ vårt förhållande till den östra grannen, till vårt öde", ${ }^{35}$ kommenterar Tikkanen, som frivilligt hade lämnat sitt hem som sextonåring för att strida mot Sovjetunionen vid fronten i fortsättningskriget och kom tillbaka traumatiserad för resten av sitt liv. Att göra upp med sina krigsminnen i pacifistisk och antimilitaristisk anda blev senare en röd tråd i hans författarskap. ${ }^{36}$ Det tengströmska idémässiga arvet, gångbart i finlandiseringens efterkrigstid, var således viktigare än lägenheten; Henrik prioriterade alltså det symboliska kapitalet framför det ekonomiska.

På samma linje är Henrik också i sin strategi att lura tvillingarna vad beträffar böckerna som ingick i arvet: han staplar dem i tre högar, de goda böckerna (till exempel Goethes och Schillers samlade verk på tyska) i en hög och de snyggt inbundna böckerna (till exempel Casanovas memoarer) i två andra högar - och på så sätt lyckas han få den för honom värdefulla högen. ${ }^{37}$ Det enda av ekonomiskt värde som han får är en antik fruktkorg av silver. Eftersom den inte har något symboliskt värde för Henrik - vilket han inte glömmer att framhålla i sin bok - säljer han den och kan på så sätt betala resan till Italien tillsammans med sin andlige fader, den kommunistiske finskspråkige poeten Arvo Turtiainen. ${ }^{38}$ Henrik är övertygad om att man kan finna Arvos (kommunistiska) sanning överallt i Europa, i varje land där man söker, och att Arvo vill visa den för Henrik. Härmed menas den sanning som burats in av kapitalisterna som omger sig med folk som ljuger för dem. ${ }^{39}$

34. För en historiskt mera korrekt beskrivning av Tengströms position och roll, se Gustav Björkstrand, Jacob Tengström. Universitetsman, kyrkoledare och nationsbyggare, SSLS 722, Helsingfors: Svenska litteratursällskapet i Finland 20I2, särskilt s. II, 205-223.

35. Tikkanen, Bävervägen, s. 8-9.

36. Jfr Wrede, Tikkanens blick, t.ex. s. II, I9 och passim.

37. Tikkanen, Bävervägen, s. 9.

38. Enligt Wrede var det dock inte hela sanningen bakom resans finansiering; jfr Wrede, Tikkanens blick, s. II3.

39. Tikkanen, Bävervägen, s. IO, 5 O. 
På så sätt skapar författaren precis som Flaubert ${ }^{40}$ betingelserna för ett slags sociologiskt experiment: tre (hos Flaubert fler) ynglingar, tillfälligtvis förenade av sin gemensamma position som bröder (hos Flaubert studenter), kastas in i rummet, och deras banor determineras av förhållandet mellan fältets krafter och deras egen tröghet. Vid första anblicken ser det ut som att Henriks bröder är ute efter ekonomiskt kapital och Henrik själv efter ett annat, främst symboliskt sådant.

\section{Det sociala rummets struktur}

Bävervägen utspelar sig i Helsingfors, för det mesta i stadens centrum. I boken nämns Esplanaden, Runebergsgatan, Stockmanns varuhus, Sandvikskajen, Norra Järnvägsgatan, Tölö, Degerö, Ilmarigatan, Arkadiagatan, Topeliusgatan, Museigatan och restaurangerna Kämp, Royal, Börsklubben och La Rotonde.

Brändö, en ö som numera hör till Helsingfors och som gav Tikkanens första adressbok dess namn, finns fortfarande med även i den andra adressboken och representerar det samma som familjen Dambreuse i Hjärtats fostran, den första polen, det vill säga "politiken och affärerna"; "de flesta [här] var döpta till direktörer". ${ }^{41}$ En stor del av Henriks sociala kapital härstammar härifrån: hans familj, hans vänner, vänner till familjemedlemmarna (brödernas affärskompanjoner), hans blivande hustru och hennes berömda familj. Att Henrik bor en kort tid på Bävervägen i förorten Hertonäs innebär för honom ett slags tillfällig deklassering. Här kan man urskilja en parallell till journalisten Falks läge i Röda rummet: ${ }^{42}$ "[jag] blev sovstadspionjär i en av de första förorterna där tråkigheten kliade som en yllepyjamas." ${ }^{43}$ Senare lyckas han dock flytta över till Brändö igen.

Den andra polen, "konsten och politiken" (familjen Arnoux hos Flaubert), representeras av de bohemiska konstnärscirklarna som träffas på restaurangen Elite, ${ }^{44}$ teaterlivet och "kulturkommunisterna", och speciellt av den krets av konstnärer som står Henrik närmast

\footnotetext{
40. Se Bourdieu, "Prolog", s. 47 .

4I. Tikkanen, Bävervägen, s. 2I.

42. Se Gedin, "Kalfstek och rosor", s. 49.

43. Tikkanen, Bävervägen, s. 97.

44. Ibid., s. Io6-Io7.
} 
(och som kan jämföras med Röda rummets cirkel) ${ }^{45}$. Inom den har var och en sin egen strategi. Skulptören Sakari Tohka, den nye maken till Henriks mor, som gör monument till hjältegravar, ${ }^{46}$ förutspår att Henrik blir en stor konstnär och inviger som äldre och mer konsekrerad honom i konstens värld. I kretsen ingår också målaren Åke Mattas som av omgivningen betraktas som det oförstådda geniet, Per Anders Stenius som är långt ifrån ett geni och Timo Sarpaneva som är Henriks granne på Bävervägen. ${ }^{47}$ Den här kretsen vill Henrik mäta sig med:

Trots att jag aldrig sa det hoppades jag att jag en dag skulle bli ännu mycket större än Timo, större än Åke och Per och Sakari, jag skulle bli mästare, en riktig mästare. Och för att bli det slet jag som en hund. ${ }^{48}$

De två bourdieuska världarna, pengarna och konsten, som dock aldrig är helt separata - tvärtom definierar de varandra och gränsen mellan dem är flytande - motsvaras i Hjärtats fostran också av den beräknande och den rena kärleken. Den förra har två grenar, den borgerliga formen (fru Dambreuse) och den "mindervärdiga" formen (den prostituerade Rosanette); den senare representeras av fru Arnoux. ${ }^{49}$ Den borgerliga formen företräds i Bävervägen av Tikkanens första hustru som han finner - naturligtvis - på Brändö och som är dotterdotter till Henriks författarkollega Ester Ståhlberg, hustru till Finlands första president K.J. Ståhlberg som Henrik ofta är gäst hos. Bröllopet äger till och med rum i presidentens hem. Orsaken till att Henrik gifter sig är en riktig borgarbrackas: han vill genom äktenskapet uppnå stabilitet och trygghet i livet för att kunna ägna sig åt sitt arbete. ${ }^{50}$ Därtill har han lovat maktens och politikens fält att gifta sig med flickan: "Jag hade lovat en president att jag skulle gifta mig i morron." ${ }^{11}$ Även två prostituerade finns med i boken: Gigi - en kvinna med vilken

45. Jfr Gedin, "Kalfstek och rosor", s. 58 .

46. För mer om Sakari Tohka och hans förhållande till Tikkanens familj se Wrede, Tikkanens blick, s. 63-68.

47. Tikkanen, Bävervägen, s. I8-20, 27, 36, 98, гог.

48. Ibid., s. 99.

49. Bourdieu, "Prolog", s. 62, 67-68.

50. Tikkanen, Bävervägen, s. 79, 84-88.

51. Ibid., s. 87. 
Tikkanen slår vad om att kunna ligga med henne sju gånger strax efter varandra ${ }^{52}$ - och den italienska Maria ${ }^{53}$ från Genua som genom att låtsas ha ett förhållande med Henrik lyckas lura honom på pengar. ${ }^{54}$ Den rena kärleken representeras av Brita, som vill rymma med Henrik för att inte behöva gifta sig med en av hennes högborgerliga föräldrar utvald man - men hon ändrar sig sedan och dör snart. ${ }^{55}$ Och särskilt finner Henrik den rena kärleken hos sommarvikarien Märta på Hufoudstadsbladets redaktion, som Henrik på bokens slutsidor plötsligt blir förälskad i och som han i hemlighet träffar i sju år tills hon gifter sig med en annan man, för att efter tre veckor återuppta sitt förhållande med Henrik. ${ }^{56}$ Deras relation mynnar ut i Henriks och Märtas samlevnad och äktenskap i den tredje adressboken. ${ }^{57}$

\section{Vacklan mellan den konstnärliga och den kommersiella polen}

I Hjärtats fostran är huvudgestalten Frédéric den som inte lyckas investera i något av de konstens eller pengarnas spel som den sociala världen skapar och erbjuder, han är med andra ord oförmögen att ta verkligheten, det vill säga insatserna i de påstått seriösa spelen, på allvar. Den obeslutsamme och osäkre Frédéric är därför, på ett dubbelt motsägelsefullt sätt, förutbestämd till obestämdhet. Placerad mitt i ett kraftfält mellan den ekonomiska eller politiska maktens pol och den intellektuella eller konstnärliga prestigens pol, befinner han sig $\mathrm{i}$ en tyngdlös social zon där de krafter som tillfälligt kompenserar eller uppväger varandra driver honom i den ena eller andra riktningen. Frédéric reflekterar inte över att han inte kan spela på båda planhalvorna och försöka vinna allt utan att samtidigt riskera att förlora allt. Han vacklar mellan strategier som utesluter varandra. ${ }^{58}$

Min tes är att Henrik som gestalt i Bävervägen har en liknande

52. Ibid., s. 29-32.

53. I Hjärtats fostran heter fru Arnoux Maria i förnamn vilket av Thibaudet tolkas som symbol för renhet (se Bourdieu,"Prolog", s. 44); både hos Strindberg och Tikkanen är dock gestalter vid namn Marie/Maria prostituerade (jfr Gedin, "Kalfstek och rosor", s. 56, 6I) - vilket kanske kan läsas som provokation.

54. Tikkanen, Bävervägen, s. 6I-68.

55. Ibid., s. $76-78$.

56. Ibid., s. $\mathrm{I} 37-\mathrm{I} 45$.

57. Jfr Henrik Tikkanen, Mariegatan 26 Kronohagen, Helsingfors: Söderströms 1977.

58. Se Bourdieu, "Prolog", s. 5I-52, 59, 79. 
position som Flauberts unge manlige borgare Frédéric, som har nått den punkt i karriären där han kan överblicka maktens sfärer och de möjligheter som står öppna för honom. Henrik är också en vacklande person, en obestämd varelse, eller snarare bestämd till subjektiv och objektiv obeslutsamhet; även om han inte är en ekonomiskt oberoende rentier som Frédéric så byter han kvinnor och älskarinnor lika frekvent, vilket är en viktig parallell. ${ }^{59}$ Tikkanens doxa, det vill säga hans egna trosföreställningar, ${ }^{60}$ nihilismen hänger också samman med hans omåttliga alkoholkonsumtion och framgår tydligt av bokens motto, "INGENTING är ändå någonting för en nihilist" ${ }^{61}$. Detta synsätt konstrueras i boken som en motsättning till Arvo Turtiainens kommunistiska doxa, som Henrik koketterar med men slutligen inte anammar som sin egen. ${ }^{62}$ Men att han inte tar verkligheten på allvar kan också ges en annan, alternativ förklaring i det bourdieuska avseendet: att inte lyckas investera i något av konstens eller pengarnas spel leder till nihilism.

\section{Världens bästa tidningstecknare}

Ganska snart avslöjar Henrik - med anledning av sin flitiga verksamhet som tecknare - att han ändä är intresserad av pengarna och att han inte riktigt bryr sig om den rena konsten:

Jag hade planer på att expandera och tänkte bli lika rik och berömd som Walt Disney. Jag trodde att min lycka var gjord bara jag hittade på den rätta seriefiguren. Att min verksamhet skulle ha någonting med konst att göra föll mig inte in. Så seriöst såg jag på riktig konst. ${ }^{63}$

Han erkänner direkt att han inte vill att publiken så småningom börjar spara och förvara hans alster; han vill tala till den kontinuerligt, i tiden:

Det viktiga för mig var inte att folk klippte ut min teckning och hängde den på sin vägg utan att de ville se min nästa teckning i

59. Om Frédérics ombytlighet, se ibid., s. 40, 6I-62.

6o. Se Broady, "Inledning", s. 6.

6r. Tikkanen, Bävervägen, s. [5].

62. Ibid., s. 55, 73 .

63. Ibid., s. I2. 
följande nummer av tidningen. Jag ville tala till dem oavbrutet, leva och växa inför deras ögon. Jag var utan tvivel en exhibitionist, en utställare. Jag ville ställa ut oavbrutet. ${ }^{64}$

Som förebilder nämner han Albert Engström, Honoré Daumier och Birger Lundqvist och bestämmer sig för sin egen strategi: "Jag skulle bli världens bästa tidningstecknare." ${ }^{\prime 5}$

Att skaffa sig pengar för att leva och dricka genom att rita lättklädda brudar och förse bilderna med tvetydiga skämt beskriver han själv som en form av prostitution i veckopressen utan några som helst konstnärliga förtjänster, men menar att just hans otyglade exhibitionism hindrar honom från att göra annorlunda. Han vill se sina alster i tryck även om han vet att han därför aldrig kommer att bli betraktad som en allvarligt syftande konstnär. ${ }^{66}$ Med andra ord: "Konst och trycksvärta går inte att blanda i Finland." ${ }^{67}$ Likadant ser han på sin litterära verksamhet: den första bok han skriver har enligt honom inga konstnärliga kvaliteter. ${ }^{68}$ Gedin konstaterar i sin studie att det i Röda rummet som utkom år 1879 enbart är det ekonomiska kapitalet som betonas: tillgången och främst bristen på pengar är den viktigaste enskilda faktor som styr bokens aktörer. Den politiska och ekonomiska makten segrar över samtliga upprorsandar; det finns ännu inget autonomt kulturellt fält. ${ }^{69} \mathrm{I}$ Tikkanens bok, som beskriver ett skede nästan 70 år senare då utvecklingen av ett autonomt fält har framskridit väsentligt, går däremot som en röd tråd jagberättarens medvetande om att det autonoma konstnärliga fältet finns men att han som tidningstecknare inte får tillträde till det.

En viktig konsekrationsinstans på det autonoma fältet är för Tikkanen De ungas utställning. ${ }^{70}$ När han bestämt sig för att slå sig fram

64. Ibid., s. I4. Det är kanske ingen tillfällighet att han efter Brändövägen 8 (tillsammans med sin författarkollega Christer Kihlman) i pressen började kallas blottare.

65. Tikkanen, Bävervägen, s. I4.

66. Ibid., s. 33-34.

67. Ibid., s. 34 .

68. Ibid., s. 46 .

69. Gedin, "Kalfstek och rosor".

70. Enligt Kruskopf mottogs Tikkanen första gången till De ungas utställning år I947, och deltog i utställningen åtminstone åren I95I och 196r. Jfr Kruskopf, Tecknaren Tikkanen, s. I04, I07. 
i tidningsbranschen börjar han kalla sig konstnär, men inte högt så att någon hör, för "[...] ingen var konstnär innan han deltagit två gånger i De Ungas utställning i konsthallen och därigenom blivit berättigad att anhålla om medlemskap i Konstnärsgillet." ${ }^{\prime 1}$ Ärelystnaden gör dock att han - som en vacklande aktör - försöker göra ett genombrott också som "riktig konstnär". Han lämnar in sina alster just till De ungas utställning. Han blir denna gång refuserad som "dålig", vilket han själv tolkar som "tidningstecknare", ${ }^{72}$ han lyckas dock få in sina arbeten på utställningen senare. Han är ändå omedveten om det autonoma fältets långvariga konsekrationscykel: han blir bitter för att ingenting händer, han blir inte genast en stor mästare och konsthandlarna kämpar inte genast om hans tavlor. Han bearbetar sitt misslyckande med cyniska och ironiska kommentarer. Orsaken till det ser han $\mathrm{i}$ att tavlorna gjorts med förbundna ögon och att resultatet därför ser ut som darrande binnikemaskar. Till och med juryns ordförande har rekommenderat den här metoden för honom som hans enda möjlighet att skapa konst. ${ }^{73}$

\section{"Den tredje sektorn"}

Besviken på den "riktiga" konsten och oförstående inför den återvänder Henrik Tikkanen till journalistiken. ${ }^{74}$ Strategin har sociologiska förutsättningar som hänger samman med efterkrigstidens växande välfärd och I940-talets finländska boom inom tidnings- och tidskriftsutgivning, också av skämttidningar, som var speciellt lämpliga för Tikkanen. ${ }^{75}$ Han ser inte någon egentlig konkurrens omkring sig, "[d] et var lättare att bli bäst som tidningstecknare i ett land där det inte fanns några tidningstecknare" ${ }^{76}$, och såg sig inte som speciellt begåvad:

Min begåvning var inte så påtaglig att nån på allvar skulle ha försökt att förhindra min karriär. Jag räknades till de trygga medelmåttor

71. Tikkanen, Bävervägen, s. I4, jfr även s. 46 .

72. Ibid., s. 34 .

73. Ibid., s. $79^{-80}$.

74. Ibid., s. 80 .

75. Jfr ibid., s. 33, I35.

76. Ibid., s. 8 o. 
som man förutsatte ha tillräckligt med förstånd för att inte försöka sticka upp. ${ }^{77}$

Spektret av tidningar han samarbetar med är mycket omfattande, men till slut hamnar han på den största finlandssvenska dagstidningen Hufoudstadsbladet då han lyckas övertyga redaktionen om att tidningen behöver en tidningstecknare. Kollegan Benedict Zilliacus blir ett liknande identifikationsobjekt för honom som Frédéric för sin vän Deslaurier; ${ }^{78}$ han är en person vars vänskap Henrik vill vinna, ${ }^{79}$ och när Henrik träffar sin blivande (första) hustru tvivlar han inte på att hon är den rätta då hon i likhet med Bendis hustru är estniska. ${ }^{80}$

Att Henrik blir journalist bekräftar än en gång hans vacklande mellan det kommersiella och det autonoma. I Bourdieus diagram över det franska litterära fältet i slutet av I8oo-talet ligger journalistiken precis mittemellan de båda polerna. ${ }^{81}$ Även om man inte mekaniskt kan tillämpa Bourdieus forskningsresultat, som gäller Frankrike och en annan tidsperiod, på andra kulturella fält ${ }^{82}$ så har man ingen orsak att tro att journalistiken i det hypotetiska diagrammet över 1900-talets andra hälft skulle få en helt annan position. Att bli journalist och befinna sig "mittemellan", i den tredje sektorn, kunde således vara strategiskt för Tikkanen.

\section{TIKKANEN TECKNAR OCH SKRIVER OCH GER UT}

Nu går vi över till de sekundära källorna för att belysa Tikkanens bana utifrån. Något utbildningskapital i betydelsen avslutad högskoleutbildning hade han inte. Även om han tecknade i Fria målarskolan och skrev in sig vid Helsingfors universitet, tilltalade de akademiska studierna honom inte. Endast bildkonststudier inledde han, men blev snarare självlärd och tränade sina kunskaper genom att teckna dagligen i flera timmars tid. Kruskopf menar att orsaken till Tikkanens bris-

77. Ibid., s. 97 .

78. Jfr Bourdieu, "Prolog", s. 56.

79. Jfr Tikkanen, Bävervägen, s. 82.

8o. Ibid., s. 83 .

8r. Se Broady, "Inledning", s. 3.

82. Jfr ibid., s. 4. 
tande utbildning förmodligen var finansiell: när Tikkanen var tjugo år gammal måste han själv finansiera sitt liv i brist på det ekonomiska kapital som hans föräldrar drack upp. ${ }^{83}$

I skolan, från vilken han frivilligt gick ut i krig, fortsatte han, såsom Kruskopf beskriver, med det tecknande som alla barn sysslar med. Under tiden vid fronten märkte han snart att det gick bra att få in teckningar i många olika publikationer. Tecknandet blev för honom först en källa till biinkomster och ganska snart en brödföda. ${ }^{84}$ Därtill kom skrivandet; såsom Johan Wrede i biografin om författaren Tikkanen påpekar, befruktade hans författarskap tecknandet och tvärtom eftersom en teckning som illustrerade en text var lättare att sälja. Redan en enda kort rad, en vits, kunde göra teckningen intressant. Alltså började tecknaren skriva, för att ha något att illustrera. ${ }^{85}$ Även i en intervju som Inga-Britt Wik gjorde med Tikkanen år 1976 sägs det att "[h]an blev som han själv säger författare genom att vara konstnär"; 86 den intervjuades formuleringar bekräftar likaledes att han i början inte såg tecknandet och skrivandet som två skilda verksamheter utan som en enda, samt att målet med dem var att försörja sig. ${ }^{87}$

Så här tillkom hans debutbok - den som enligt honom inte hade några konstnärliga kvaliteter - det vill säga den sagoliknande och pacifistiska skrönan $M r$. Gogo kommer till Europa (I946). ${ }^{88}$ Trots sin för finlandssvenska förhållanden anmärkningsvärt stora upplaga, 3000 exemplar, blev boken snabbt utsåld, och det samma gällde delupplagan i Sverige, där Ingemar Wizelius i en recension i Dagens Nybeter som Kruskopf nämner, kallade boken en politisk satir av tvivelaktigt slag och beskyllde författaren för dålig smak. ${ }^{89}$ Det var inte sista gången Tikkanen fick höra recensentkårens negativa kritik - i hans bok om

83. Se Kruskopf, Tecknaren Tikkanen, s. IO, IOI-IO2; jfr även Tikkanen, Brändövägen.

84. Kruskopf, Tecknaren Tikkanen, s. 9-Io.

85. Wrede, Tikkanens blick, s. 24.

86. Inga-Britt Wik (red.), ”Henrik Tikkanen om vägen till författarskapet. 'Därför denna underliga aforistiska stil ...", Historiska och litteraturhistoriska studier 73, Helsingfors: Svenska litteratursällskapet i Finland I998, s. 215.

87. Ibid., s. 216, 217, 232.

88. Henrik Tikkanen, Mr. Gogo kommer till Europa, Helsingfors: Söderströms samt Stockholm: Fahlcrantz \& Gumaelius 1946. Närmare om boken se Wrede, Tikkanens blick, s. 87-92.

89. Se Kruskopf, Tecknaren Tikkanen, s. 75. 
Irland, Paddys land, utgiven år 1957, ${ }^{90}$ då den samhällsengagerade synen på litteratur var i annalkande, saknade recensenterna den irländska vardagsverkligheten som vid denna tid ännu ofta betecknades som tragisk. ${ }^{91}$ Framgång bland läsarna, det vill säga stora försäljningssiffror, och kritiska omdömen från recensentkåren ger en antydan om i vilken riktning Tikkanen var på väg - mot den kommersiella polen.

Den finska litteraturvetaren och recensenten Pekka Tarkka anser att Tikkanens författarskap huvudsakligen vuxit fram ur hans journalistiska verksamhet. ${ }^{92}$ I minnesboken Henrik skriver Juha Tanttu bland annat att Henrik svarade "Jag är journalist", om någon frågade honom vilketdera han egentligen var, tecknare eller författare. Ville man veta mera om hans journalistik, då kompletterade han stolt svaret med "Jag är tidningstecknare", en som tecknar men också kan skriva text till sina bilder och vill visa det. ${ }^{93}$ Tikkanen kom att arbeta på Hufoudstadsbladet i 20 år (1947-1967). Också där publicerade han från första början både bild och text; man ser en gradvis utveckling i den bemärkelsen att Tikkanen först illustrerade andra skribenters texter men senare allt mera också ville skriva själv. Till hans favoritgenrer hörde till exempel vitsar, korta textrader, skämtsamma repliker med tillhörande teckning och förklarande texter till teckningar som så småningom omformades till aforismer. Allt publicerades på tidningens "lätta sida", inte på kultursidorna. ${ }^{94}$

Ett betydande kapitel i Tikkanens kombinerade text- och bildjournalistik är de så kallade "henrikarna", tecknade ansikten med en kort, skämtsamt ironisk eller aforistisk text som bygger på ett samspel mellan bild och text. De fick sin början i Finlands svenskspråkiga tidningar på I950-talet. Vid tiden för Tikkanens överflyttning till den finskspråkiga tidningen Helsingin Sanomat år 1967 följde de med, och

90. Henrik Tikkanen, Paddys land. Irländska skisser, Helsingfors: Söderströms samt Stockholm: Natur och Kultur 1957 .

91. Kruskopf, Tecknaren Tikkanen, s. 74-76, 83.

92. Pekka Tarkka, Författare i Finland, Helsingfors: Söderströms I990.

93. Juha Tanttu, "Konstnären som reporter", Märta Tikkanen (red.), Henrik, Helsingfors: Söderströms 1985 , s. 93.

94. Dlask, "Finskans rika valörer", s. 246-268; Wik, "Henrik Tikkanen om vägen till författarskapet", s. 220, 227. 
nu skrev han sina karakteristiska texter till dem på finska, som han som tvåspråkig behärskade lika bra. ${ }^{95}$

Redan som skribent för Hufvudstadsbladet började Tikkanen också skriva lite längre tidningstexter, som också de med tiden blev oerhört många. Han reste mycket i sitt jobb, skrev reportage och kåserier som han illustrerade och som senare utkom samlade i böcker. När han redan hade gett ut några sådana samlingar, blev han tillräckligt djärv för att våga utveckla sina texter och bearbeta sina tidigare kåserier och reportage till verk i en mer helgjuten form (reseböcker) som dock tematiskt grundade sig på samma ämnen som han skrev om i tidningarna. De utkom naturligtvis illustrerade med hans bilder; i de fall då Tikkanens böcker är illustrerade så är illustrationerna nästan alltid gjorda av honom själv. ${ }^{96}$ Den här kombinationen av tecknande och skrivande var inte bara lönsam för honom själv, också för tidningen var det billigare att sända iväg en tecknare - fotografier var inte så vanliga i tidningar vid denna tid - och en reporter i en och samma person. ${ }^{97}$

Här ligger alltså ursprunget till det mesta som Tikkanen senare gav ut i bokform. Den här delen av hans livsverk, som ligger närmare den kommersiella polen, brukar inte nämnas som den mest kanoniserade. Det är nämligen de böcker som han skrev av ekonomiska skäl. För deras del är det inte meningsfullt att dela hans bana i två grenar, en bildkonstnärlig och en litterär sådan, för i dessa böcker står alltid bildkonst och litteratur bredvid varandra, hand i hand.

Tikkanen publicerade till och med några helt kommersiella böcker - till exempel en av varuhuset Stockmann utgiven och av honom själv redigerad handledning för personalen, Kunden till mötes (1955).

95. Dlask,"Finskans rika valörer", s. 246-268.Jfr även Wrede, Tikkanens blick, s. 40-49. 96. Det kan tilläggas att Tikkanen illustrerade böcker också för andra författare. Han kan numera ibland vara mest känd som Märta Tikkanens man, då Märta i sin roman på vers med namnet Århundradets kärlekssaga (1978) beskrev svårigheterna i livet med sin alkoholiserade make. På det finlandssvenska litterära fältet kan Märta Tikkanens roman betraktas som ett slags sjuttiotalistisk feministisk revolt mot den tidigare övervägande manliga sextiotalistiska generation som Henrik kan sägas tillhöra. Därför kan det vara överraskande att också den här romanen blev illustrerad av Henrik Tikkanen. För mera information om Henriks illustrationer i Märtas böcker se Storå, De oerhörda orden, s. 8I-82, I53, I63, I76, I78, 285-286.

97. Dlask, "Finskans rika valörer", s. 246-268. 
Han gjorde reklamteckningar, affischer och bilder till annonser, samt illustrerade Saunaseuras, det vill säga Finska Bastusällskapets engelskspråkiga småskrift Let's Have a Sauna (1966). ${ }^{98}$

\section{Det "RiKTIGA" KONSTNÄRSKAPET}

Det ovan beskrivna tyder på att Tikkanens kommersiellt orienterade författarskap och bildkonstnärskap fritt mynnar ut i varandra. I det följande visar jag att han samtidigt strävade efter att bli en erkänd författare och konstnär, vilket strider mot några av hans ovan nämnda yttranden, och därmed kommer man till den andra polen i det bourdieuska fältet, den konstnärliga och mer autonoma.

Där tävlar man - såsom det påpekats redan i början - inte om ekonomisk vinst och publikframgång utan om renommé och uppskattning bland konstnärskollegerna och kritikerkåren, och där kan man vänta på sin konsekrering $\mathrm{i}$ många decennier tills verken slutligen blir kanoniserade. Bourdieu kallar detta område subfältet för begränsad produktion ${ }^{99}$.

\section{Den Konstnärliga polen - TikKanens autonoma BILDKONST}

Även i Tikkanens bildkonstnärliga verksamhet kan man således finna - såsom Kruskopf formulerar det - en produktion som med fog kan kallas fri konst, i motsats till den brukskonst som de för reproduktion avsedda teckningarna är. ${ }^{100}$ Tikkanens bana på det här fältet beskrivs utförligt av Kruskopf; ${ }^{101}$ nedan ger jag en kort sammanfattning av hans forskningsresultat och tillägger mina egna bourdieuskt inspirerade kommentarer.

Den ovan nämnda vägen till att bli erkänd - i bourdieuska termer formulerat"specifikt konsekrerad" - också som bildkonstnär gick framför allt via de officiella utställningarna, till vilka det gällde att få sina verk antagna. Den första för Tikkanens del var Salon Strindberg

98. Se Kruskopf, Tecknaren Tikkanen, s. 99-Ioo.

99. Jfr Broady, "Inledning”, s. 4.

Ioo. Kruskopf, Tecknaren Tikkanen, s. II3.

IOI. Se ibid., s. IOI-I29. 
(1945), två år därefter antogs han till De ungas utställning. I951, efter att ha prövat på olika grafiska tekniker, accepterades han till inalles fem utställningar: De ungas utställning, Nordiska grafikunionens 20-årsexpo, Konstnärernas årsutställning, en välgörenhetsexpo och Konst på papper. Varje gång fick han både omnämnanden och omdömen i tidningspressen och av Finska konstföreningen erhöll han också ett Hoving-stipendium på 5000 mark.

Under de följande åren, på det sena 1950-talet och det tidiga I96o-talet, började Tikkanen delta med iver och framgång i samlingsutställningarna. ${ }^{102}$ I962 inköptes de första av hans alster till Åbo konstförenings och Helsingfors stads samlingar. Kruskopf påpekar dock att Tikkanen med anledning av detta också fick höra en del glåpord bland konstnärskollegerna och i utställningskommittéer och juryer, även om de inte yttrades offentligt. I mångas ögon var han inte någon "riktig" konstnär utan "bara" en tidningstecknare, ${ }^{103}$ vilket är ett symptom på ett typiskt bourdieuskt spel om de låga och de höga genrerna där bara de höga borde erkännas en specifik konsekration på subfältet för begränsad produktion. Det handlar med andra ord om det traditionella spelet kring vad som är och inte är riktig konst. Även i pressen betecknades Tikkanen som en avbildare av städer och hus, hans teckningar jämfördes med internationell illustrationskonst och avfärdades som den rutinerade reporterns kanske lite mera omsorgsfullt utförda blad.

Gliringarna resulterade i en tilltagande ovilja från Tikkanens sida att delta i samlingsutställningar, vilket r971 kulminerade i en dramatisk ordväxling i samband med jurybedömningen av Konstakademins treårsutställning på Ateneum, till vilken hans teckningar inte hade godkänts. Tikkanen skrev först en ilsken kommentar till Helsingin Sanomat där han samtidigt meddelade att han avgår ur fackföreningarna, då han ansåg att fackföreningsrepresentanterna i juryn var skyldiga till refuseringen. Enligt hans mening var orsaken uteslutande den att han också var verksam som tidningstecknare och att juryn tydligen ansåg att hans rykte som sådan satte sin prägel på

I02. För detaljerad lista se Kruskopf, Tecknaren Tikkanen, s. I07-Io8.

I03. Jfr Tanttu, "Konstnären som reporter", s. 93: "Han tålde inte att han på sin tid fick höra att han var 'bara' tidningstecknare." 
hans bidrag, trots att de inte var några tidningsillustrationer. Efter ett svar från juryns ordförande påminde han i en dräpande kommentar om tidigare fall i konsthistorien där illustrations- och reklamarbeten upphöjts till allmänt accepterad bildkonst, men drog sig samtidigt tillbaka; han tänkte inte återvända till konstnärernas skara, utan stanna i tidningens spalter bland folket och eventuellt vänta tills gränserna förskjutits. Han fick medhåll av många utanför det autonoma fältet. ${ }^{104}$ Med andra ord kan man tala om Tikkanens "bourdieuska" uppror mot den dåvande konstakademin.

Efter 197I deltog han således för ett årtionde framöver inte längre i samlingsutställningar. I stället ökade hans intresse för att ställa ut separat både utomlands och på många ställen i hemlandet, både $\mathrm{i}$ städer och på landsbygden, ${ }^{105}$ vilket han också hade gjort förr. Denna strategi kan å ena sidan tolkas som en följd av att separatutställningarna sålde bättre än samlingsutställningarna vilket även bekräftas av Kruskopf; Tikkanens verk inköptes även till offentliga samlingar. ${ }^{106}$ Å andra sidan lade Tikkanen nu på sina egna separata utställningar allt mera vikt vid att ställa ut arbeten som befann sig så fjärran som möjligt från dagsrutinens journalistiska illustrationsarbeten, det vill säga från den brukskonst som inte betraktades som riktig konst på det autonoma subfältet för begränsad produktion. Det blev för det mesta modellteckningar, fantasiteckningar, landskap och aktstudier, sådana alster som ligger närmare den autonoma polen än tidningsillustrationer med texter. Om det fanns texter var de antingen "kalligrafiska excesser" ${ }^{107}$, oläsliga och snarare möjliga att tolka som dekorativa tillägg, eller utförda som poetiska kommentarer av Bo Carpelan, Tikkanens författarkollega som han ofta och gärna samarbetade med. De kunde också vara gjorda som reklamcollage med Tikkanens egna ironiska teckningar. I detta kan man se Tikkanens strategi att bli av med sin stämpel som enbart tidningstecknare och avbildare av städer och hus, som "en stadshora" ${ }^{108}$, något han kallats då hans Helsingforsvyer och bilder av byggnader kommit till användning

I04. Debatten sammanfattas utförligare i Kruskopf, Tecknaren Tikkanen, s. III.

I05. För detaljerad lista se ibid., s. II2-II3.

Io6.Jfr ibid., s. II2.

I07. Ibid., s. II5.

Io8. Ibid., s. II4. 
i reklamannonser och -affischer och i en serie tallrikar som Arabia tillverkade på i96o-talet.

Sin kanske största framgång fick Tikkanen med sin utställning på Galerie Hörhammer år 1975. 1979 ägde en stor utställning rum på Amos Andersons konstmuseum i Helsingfors med 400 av Tikkanens teckningar indelade i 23 grupper. 1979-I981, några år före sin död, ställde Tikkanen ut mycket utomlands, till exempel i Stockholm och London där han redan var känd på grund av sina adressböcker - vilket väckte intresse för honom också som bildkonstnär - och i Wiesbaden, Bonn och Düsseldorf, där hans verk till och med ställdes ut bredvid en utställning av August Strindbergs måleri. Efteråt transporterades de 57 utvalda bilderna till Göteborgs konstmuseum där de sedan dess uppbevarats. Gränserna försköts, precis som Tikkanen hade förutsagt; man slutade betrakta hans teckningar gjorda för tidningar och böcker i motsättning till hans mer autonoma och frikonstnärliga teckningar. Bland de göteborgska bilderna finns nämligen, vid sidan av familjeporträtt och en serie bilder kring dödstemat, också några "henrikar" och illustrationer. En öppen fråga är om det var hans arbete vid den autonoma polen som upphöjde tidningsprodukterna eller om de senare successivt uppvärderades i sig - samt om detta skedde enbart i Tikkanens fall eller om genren generellt fick högre status. Ett faktum är dock att Tikkanen också blev konsekrerad som en autonom konstnär genom utställningarna och konstmuseerna, inte bara som tidningstecknare.

\section{DEN KONSTNÄRLIGA POLEN - LITTERATUR}

En intressant aspekt av Tikkanens strävan mot det litterära fältets konstnärliga, autonoma pol är hans försök att frigöra sig från kopplingen till teckningen och bilden. ${ }^{109} \mathrm{Vid}$ sidan av några av hans krigsböcker

Io9. I intervjun med Inga-Britt Wik avslöjar han: "En stor del av min stil i dag beror inte alls på några förebilder utan beror på att jag började skriva bildtexter i stället för egentliga texter. Och bildtexter betyder att bilderna talar för sig och texterna bara kompletterar det som inte bilderna säger. När du lämnar bort bilderna blir det en alldeles speciell sorts text som får en alldeles annan karaktär. Den är unik och det beror ingalunda på att jag är unik utan att mitt förfaringssätt är det. Att jag har blivit en sådan författare som jag är beror på det unika sätt som jag har blivit författare, jag har blivit det genom att vara konstnär. [...] Först var det bilden, så 
- av vilka flera skrevs på finska och i litteraturhistorierna betraktas som framstående i den postmodernistiska krigsgenren - brukar ofta två romaner och en självbiografi nämnas som hans mest betydande verk: Hjältarna är döda (196r), Ödlorna (1965) och Brändövägen 8 (1975). Alla tre är mer eller mindre självbiografiskt förankrade - de anknyter tematiskt till varandra och bekräftar Tikkanens ökande säkerhet som författare. ${ }^{110} \mathrm{I}$ de här böckerna ingår bara en teckning av Tikkanen, på omslaget. ${ }^{111}$ I följande avsnitt skisserar jag hur det autonoma litterära fältet såg på verken, speciellt beträffande deras förhållande till Tikkanens tidningsverksamhet som var en prövosten för det autonoma bildkonstnärliga fältet.

\section{Hjältarna är döda}

Hjältarnas $^{112}$ reception blev ingen katastrof: man konstaterade att Tikkanen hade talang och han uppmanades att skriva vidare och arbeta på sina uttrycksmedel. Men samtidigt påtalade Nya Pressens anmälare Sören Lindgren den svaga, ställvis direkt banala och naiva miljöskildringen, att fogen mellan människa och miljö glappade och att upplevelsen av liv saknades. ${ }^{113}$ Inte heller Hufoudstadsbladets Nils-Börje Stormbom ville tala om en nyckelroman, då boken enligt

kom texten till bilden, och slutligen lämnade jag bort bilden och lämnade kvar bara texten, vilket garanterat är någonting unikt, vad jag vet, jag har inte hört att någon annan skulle ha kommit på den metoden. Därför denna underliga aforistiska stil som hela tiden förefaller att säga mer. Lustigt nog ser människorna uppenbarligen de bilder som inte finns, för jag skriver dem med bilderna framför ögonen. Jag har en vision av en bild och så skildrar jag den i en text, men jag lämnar bara bort bilderna, och så har du texten. Där är boken. Det är väl en metod lika bra som en annan, men den är väl aldrig tidigare prövad?"Wik, "Henrik Tikkanen om vägen till författarskapet”, s. 220.

Iı. Se t.ex. Trygve Söderling, "Sextio- och sjuttiotalsprosa”, Clas Zilliacus (utg.), Finlands svenska litteraturbistoria. Andra delen: Igoo-talet · Uppslagsdel, Helsingfors: Svenska litteratursällskapet i Finland \& Stockholm: Bokförlaget Atlantis 20oo, s. 293; Clas Zilliacus, "Finlandssvensk litteratur", Clas Zilliacus (utg.), Finlands svenska litteraturhistoria. Andra delen: I9oo-talet · Uppslagsdel, Helsingfors: Svenska litteratursällskapet i Finland \& Stockholm: Bokförlaget Atlantis 200o, s. I7.

III. Se Henrik Tikkanen, Hjältarna är döda, Helsingfors: Söderströms I96r; Henrik Tikkanen, Ödlorna, Helsingfors: Söderströms I965; Tikkanen, Brändövägen 8.

II2. För närmare diskussion av det litterära innehållet se Wrede, Tikkanens blick, s. IO4-II2.

II3. Sören Lindgren, "Hjältars svårigheter", Nya Pressen 5/6 ig6r. 
honom uppvisade en viss ytlighet. ${ }^{114}$ Sven Willner i den regionala tidningen Västra Nyland uppfattade också en sådan ytlighet särskilt i människoskildringen och skrev att boken rymde alltför många väsensskilda element och som roman betraktad kanske inte var så märklig. ${ }^{115}$ Även en annan anmälare i Landsbygdens folk menade att författaren inte trängde särskilt djupt under ytan på sina personer. ${ }^{116}$ Inte heller Gudrun Mörne, den socialdemokratiska Svenska Demokratens anmälare, såg Hjältarna som någon alltigenom stark roman, bland annat på grund av att några gestalter skildrats som karikatyrer och andra som levande gestalter - och mellan de här två kategorierna kunde det inte bli något samspel. ${ }^{117}$

Intressant är recensenternas uppfattning att Tikkanens journalistyrke inte var den bästa utgångspunkten för karriären på det rent skönlitterära fältet; här kan man igen iaktta det bourdieuska - nu litterära - spelet om de låga genrerna (journalistik) och de höga (skönlitteratur, diktning). Många av recensenterna menade att hans verksamhet som kåsör hade inverkat menligt på resultatet. Stormbom ansåg att Tikkanen inte var en riktig fiktiv diktare; snarare närmade sig hans grepp reporterns och den skönlitterära dräkten tjänade blott som nödtorftigt kamouflage. Det han gav var endast en närapå fotografisk skildring av en viss miljö och boken hade sitt värde bara som dokument. ${ }^{118}$ Inte heller enligt Stig Sjödin i den sverigesvenska Stockholms-Tidningen var Hjältarna med sin vaghet i personteckningen någon stor roman, bara ett mycket intressant dokument. ${ }^{119}$ Åbo Underrättelsers Ole Torvalds menade likaså att kåsören och den snärtiga tecknaren inte förnekade sig i boken med dess många schablonmässiga drag, vilket i sammanhanget var lite synd; recensenten rekommenderade mindre nonchalant ironi och mera analytiskt allvar. ${ }^{120} \mathrm{~N} \mathrm{~V}$ i Studentbladet reflekterade djupare över hur tidningskåsören lätt föll in i "klyschartade" tongångar. För tidningsmannen, till skillnad från författaren, gällde att kunna

\footnotetext{
II4. Nils-Börje Stormbom, "Missanpassade", Hufvudstadsbladet 7/6 I96r.

II5. Sven Willner,"I Helsingfors I944", Västra Nyland I5/6 I96I.

II6. [Anonym], "Döda hjältar", Landsbygdens folk 28/7 I96r.

II7. G[udrun] M[örne], "Hjältarna är döda", Svenska Demokraten I8/8 I96I.

II8. Stormbom,"Missanpassade".

II9. Stig Sjödin, "De döda hjältarna”, Stockholms-Tidningen 30/7 I96r.

I20. Ole Torvalds, "Vilsna f d hjältar", Åbo Underrättelser 3/9 I96r.
} 
tänka och skriva snabbt, men ohjälpligen gav boken ett intryck av att "ha blivit hopkastad på några få veckor". ${ }^{121}$ Tammerfors Aftonblads Don Herler påstod att boken var skriven med flyhänt penna i reportagestil, vilket var dels en fördel, dels en nackdel. ${ }^{122}$ Bara Margaretha Romberg på Ny Tid uppskattade den väsentliga, krasst satiriska bilden av samhället tecknad av kåsörens hand - vilket också kan tolkas mot bakgrund av tidningens vänsterradikala prägel. ${ }^{123}$

\section{Ödlorna}

Nästa bok, Ödlorna ${ }^{124}$, blev en större framgång, speciellt på grund av sitt pacifistiska budskap. Borgåbladets anmälare Helmer Wahlroos menade att krigets vardag inte kunde framställas avskyvärdare än med Tikkanens "teckningar i ord"; ${ }^{125}$ den intressanta formuleringen signalerar att Tikkanens roll som bildkonstnär flyter in i bedömningen. "Tikkanens engagemang är brännande och kräver ett svar av oss, det riktiga svaret”, skrev Nya Pressens Bengt Pihlström. ${ }^{126}$ Sven Willner konstaterade i Västra Nyland att Ödlorna hade en större stramhet, en fastare komposition och en större slagkraft än Hjältarna, och den psykologiska förenkling Willner också nämner var enligt honom bara en liten detalj. ${ }^{127}$ Svensk Ungdoms Pauli W. Leiponen skrev - med anledning av en enligt honom mycket viktig bok som inte kunde kringgås - redan om några typiska "tikkanenska" drag; trots att grundattityden hade bibehållits var steget från Hjältarna till Ödlorna långt. I sitt slag var boken enligt Leiponen unik i den finlandssvenska litteraturen, angelägen som ett konkret smärtsamt hugg och gestaltad med övertygande konstnärligt kunnande, i "klangstyrka" jämförbar med en Christer Kihlman ${ }^{128}$ - det vill säga en författare som år I965 definitivt hade större symboliskt kapital på det litterära fältet än Tikkanen. Hufoudstadsbladets recensent J.O. Tallqvist var inte helt nöjd

I2I. N V, "Mot ingenting", Studentbladet I7/9 I96r.

I22. Don Herler, "Frän uppgörelse!", Tammerfors Aftonblad 2/I 1962.

I23. M[argaretha] R[o]m[ber]g, "Inga hjältar", $N y$ Tid I/9 r96r.

I24. Närmare om bokens litterära innehåll se Wrede, Tikkanens blick, s. II7-II9.

I25. H.[elmer] J. W[ahlroos],"Två böcker: En anklagelse och en narrspegel”, Borgåbladet 2/I2 I965.

I26. Bengt Pihlström, "Intensiv protest mot krigets vanvett", Nya Pressen I9/II 1965.

I27. Sven Willner,"Krig, i all oändlighet", Västra Nyland 4/I2 I965.

I28. Pauli W. Leiponen, "Ödlorna", Svensk Ungdom I965:5-6. 
med kontrasten mellan Tikkanens stil och syften men hävdade att författarens nya satiriska berättelse på ett respektingivande sätt vittnade om hans litterära ambitioner och konstnärliga intentioner. ${ }^{129}$

Angående de journalistiska inslagen i boken hade anmälarna skilda meningar. Enligt en av dem, Don Herler i Syd-Österbotten, skrev Tikkanen kåserier med smak av reportage. ${ }^{130}$ Även Gösta Ågren i Ny Tid hade likartade invändningar, trots att Ödlorna gav honom det starkaste intrycket av alla säsongens finlandssvenska litterära prestationer; den vassa satiren i signaturen Henriks penna hade enligt honom sällan varit vassare, ärligare och bittrare. Ågren menade att författaren hade skrivit lite för mycket, framför allt kåserier: språket var ett så lydigt redskap i hans hand att det ibland kändes nött. Han uppmanade Tikkanen till ett sabbatsår för att rena prosan, för hans begåvning var stor och han borde inte nöta bort den ${ }^{131}$ - så här visade den vänsterradikala tidningen igen sin vilja att investera i författaren även om han inte tillhörde dess kretsar.

Att Tikkanens stil har förbättrats konstaterar Nils-Börje Stormbom, som fyra år efter sin tidigare kritiska recension numera var skribent på Vasabladet. För honom är Ödlorna redan en noga beräknad och effektiv helhet, för"[h]an [Tikkanen] har också arbetat ihärdigt med uttrycksmedlen och skrivit sin hittills bästa bok även i rent stilistisk mening”. ${ }^{132}$ Enligt Borgåbladets recensent Helmer Wahlroos är det nu inte kåsören Tikkanen som producerar sig i underfundiga små samhällssatirer: detta är Tikkanens version av Bertha von Suttners Ned med vapnen. ${ }^{133}$ Och Ole Torvalds skriver i Åbo Underrättelser att Ödlorna inte kan sägas ligga nära de lätta och nonchalanta litteraturarterna som kåseri och revy trots att boken stilistiskt är flyhänt, snabb och lätt i språkrytmen. ${ }^{134}$

Ödlorna var alltså en klart större kritikerframgång än Hjältarna - men någon försäljningsframgång blev romanen till skillnad från

I29. J.O. Tallqvist, "Splittrad vision - svart humor", Hufvudstadsbladet 2I/II I965.

I30. Don Herler, "Ur bokfloden. Skärvor av våld", Syd-Österbotten I3/I I 666.

I3. Gösta Ågren, "Ödlornas brand", Ny Tid I8/2 I966.

I32. Nils-Börje Stormbom, "Att kämpa för livet", Vasabladet 3/12 I965.

I33. H.[elmer] J. W[ahlroos], "Två böcker: En anklagelse och en narrspegel".

I34. Ole Torvalds, "Om ordets kamp mot våldet och om två nya prosaböcker", Åbo Underrättelser $23 / \mathrm{II} 1965$. 
Tikkanens tidigare böcker inte, vilket föranledde författaren att skriva ett kåseri för Hufvudstadsbladet med rubriken "Hur en författare blir framgångsrik utan att vara det". ${ }^{135}$ Det är ett uttryck för Tikkanens "bourdieuska" erfarenhet att lovord bland kritikereliten inte betyder att man omedelbart säljer - och vice versa. Nu är det den motsatta, konstnärliga polen som Tikkanen rör sig mot.

\section{Brändövägen 8}

Den största framgången bland det litterära etablissemanget vid den autonoma polen nådde Tikkanen först år 1975, vilket är intressant eftersom motsvarande framgång på det bildkonstnärliga autonoma fältet, med Hörhammer-expon, inträffade samma år. Tikkanen, $5 \mathrm{I}$ år gammal, gav ut sin första självbiografiska adressbok, Brändövägen $8^{136}$, och mottagandet av boken var lysande speciellt i Sverige och i det finskspråkiga Finland. Även det finländska, svenskspråkiga Hufvudstadsbladets skribent Ingmar Svedberg skrev om Tikkanen som en allt mera oumbärlig författare, som säger obehagliga sanningar rakt upp i ansiktet med en humor och stilkonst som får allt mera imponerande drag. Mottagandet i Svenskfinland var annars splittrat, men inte på grund av de journalistiska inslagen (som inte alls nämndes), utan på grund av den diskussion som uppstod om gestalternas representativitet för finlandssvenskarna i gemen och för den finlandssvenska borgerligheten.

Först under denna period, i mitten av I970-talet, började Tikkanen få litteraturpris, just för den här boken: Eino Leino-priset, statspriset för litteratur och ett pris från Paul Werner Lybecks fond. ${ }^{137}$ Det är inget under att just Brändövägen 8 blev den bok som senare, åren 1996 och 2004, skulle ges ut på nytt, för den har blivit en del av en finlandssvensk litterär kanon. Bokens framgång kan ses som ett typiskt exempel på den långvariga konsekrationen på det bourdieuska subfältet för begränsad produktion.

135. Se Wrede, Tikkanens blick, s. I18.

136. För mer om Brändövägen 8 se Wrede, Tikkanens blick, s. I7I-I89.

137. Jfr Dlask, Debata Tikkanen-Kiblman. Preludium. Díla-príjetí-polemika, s. I47-I95, 253; Dlask, "Tikkanen-Kihlman-debatten", s. 256-258, 268; Wrede, Tikkanens blick, s. $190-225$. 


\section{Avslutining}

Den "bourdieuska" och "gedinska" analysmodellen har visat sig vara ett relevant verktyg för att beskriva och analysera Tikkanens bana. Jämför man de två banorna - inom det bildkonstnärliga respektive det litterära fältet - kan man konstatera att litteraturkritikerna var mer uppmuntrande och hjälpsamma än bildkonstkritikerna när det gällde hans strävanden att komma närmare den autonoma polen: att skriva Henrik, gör dig av med dina journalistiska ofog, sedan blir det bra! pekar på en helt annorlunda strategi än att under många år säga Han som är tidningstecknare duger inte här!

Frédérics känslofostran innebar en tilltagande insikt om att de två världarna, konsten och pengarna, var oförenliga. ${ }^{138}$ Samma insikt fick också Tikkanen komma fram till - och sedan anpassa sin verksamhet till den pol där han ville vara verksam. I Tikkanens fall har vi att göra med en aktör som var intresserad av både pengarna och av konsten, som både inom bildkonsten och litteraturen sysslade med många lägre och högre - genrer. Tidningsteckningarna var hans levebröd, men knappast ett medel att bli rik och förmögen som ett självändamål; det var snarare en ekonomisk realitet att han inte hade råd att spela det missförstådda geniet. Tidningsteckningarna var också ett medium för information och opinionsbildning med vilket han snabbt kunde nå en publik. Därtill lyckades han flytta på gränsen mellan det låga och höga och han hade också en ambition att vara "en riktig konstnär". ${ }^{139}$ Konflikten mellan hans inträde i en konsekrerad konstnärskrets och avståndstagandet $\mathrm{i}$ form av kommersiell produktion behöver inte vara ovanlig; det kan också finnas andra liknande aktörer, och analysmodellen kan vara relevant även i deras fall.

Henrik Tikkanen, en gestalt som är vacklande på samma sätt som Flauberts Frédéric och som är synlig både i hans självbiografi och på den litterära och bildkonstnärliga bana som källorna berättar om, vågade varken investera i konstens eller pengarnas skilda spel och riskerade därför att förlora allt. Han bestämde sig för att bygga en "symboliskt" framgångsrik karriär parallellt med den kommer-

I38. Bourdieu, "Prolog", s. 62.

I39. Kruskopf, Tecknaren Tikkanen, s. I27; Tanttu, "Konstnären som reporter", s. 94. 
siella, med risk för att kommersiella framgångar skulle beröva honom symboliskt kapital. Till slut förlorade han ändå inte alls allt. Men det dröjde många decennier innan han både som autonom bildkonstnär och som autonom författare vann en position - innan han började tas på allvar. Han själv sammanfattar det här på följande sätt:

Jag har måst underhålla familjer och barn och klara det ena och det andra hela tiden, men samtidigt har jag försökt skapa en konstnärligt kvalitativ produktion, det kan jag säga fullkomligt ärligt att jag har haft konstnärliga ambitioner. ${ }^{140}$

Både inom Tikkanens litterära och bildkonstnärliga verksamhet möter man samma dikotomi mellan konst och pengar. Ur bourdieusk synpunkt är det i efterhand inte så viktigt att skilja mellan hans bana som konstnär och som författare. Med anledning av Tikkanens Gesamtkunstwerk kan man - naturligtvis med en förenkling - metaforiskt tala om ett träd med en mer kommersiell stam som växer upp ur en journalistisk mark och som rymmer dem av hans verk där han använde både text och bild. På den här kommersiella stammen växer dock ut två stora intellektuella, autonoma grenar, dels hans mer autonoma bildkonstnärliga bana, dels hans mer autonoma författarbana, där han kopplade samman text och bild i avsevärt mindre utsträckning. De här grenarna försöker således växa så långt från den ursprungliga stammen som möjligt. För Henrik Tikkanen gäller det intressanta - men inte överraskande, ty det relaterar till genrers olika status - att ju närmare text och bild står varandra, desto mer kommersiell är konsten; ju mera de går isär, desto närmare den autonoma polen, i litteraturen respektive bildkonsten, når de.

Denna artikel har tillkommit inom forskThis article is published as an output of ningsprogrammet Progres QI2: Literature the Charles University (Faculty of Arts) and Performativity (Litteratur och performativitet) vid den filosofiska fakulteten research programme Progres QI2: Literature and Performativity. vid Karlsuniversitetet i Prag.

I40.Wik, "Henrik Tikkanen om vägen till författarskapet", s. 233. 